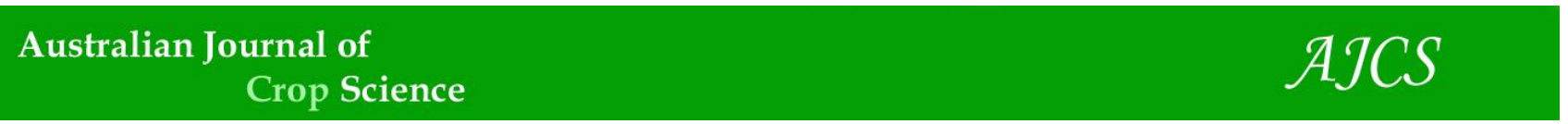

AJCS 14(08):1230-1235 (2020)

ISSN:1835-2707

doi: 10.21475/ajcs.20.14.08.p2226

\title{
Development of cabbage cultivar '60 days' seedlings on substrates formulated from babassu stem biomass
}

\author{
Samuel Ferreira Pontes ${ }^{*}$, Edmilson Igor Bernardo Almeida, Raissa Rachel Salustriano da Silva-Matos, \\ Selma Maria Dias de Moraes Costa, Rafaela Bezerra de Araújo, Sâmia dos Santos Matos, Washington da \\ Silva Sousa, Kleber Veras Cordeiro, Janaiane Ferreira dos Santos, Taciella Fernandes Silva, Ronny Sobreira \\ Barbosa and Paula Sara Texeira de Oliveira
}

\author{
Campus Professora Cinobelina Elvas, Federal University of Piauí, CEP 64900-00, Bom Jesus, PI, Brasil \\ Center for Agricultural and Environmental Sciences, Federal University of Maranhão, CEP 65500-000, \\ Chapadinha, MA, Brasil
}

*Corresponding author: samuellpontes@outlook.com

Abstract

Cabbage is a vegetable of considerable socioeconomic importance and is the fifth most widely cultivated vegetable in Brazil. In recent years, raising seedlings using locally available substrates has become a more viable alternative for small and medium-size rural producers. In this regard, we sought in this study to evaluate the development of seedlings of the cabbage cultivar '60 days' on substrates formulated from babassu stem biomass. Research was carried out in a greenhouse covered with a shade screen providing $50 \%$ light interception. The experimental design was completely randomized with six treatments, four repetitions, and eight plants per replicate. The treatments consisted of the following substrates formulated using different proportions of babassu stem biomass (BSB) and sand: S1 - $100 \%$ sand; S2 - $20 \%$ BSB + $80 \%$ sand; S3 - $40 \%$ BSB + $60 \%$ sand; S4 - $60 \%$ BSB +40\% sand; S5 $80 \%$ BSB $+20 \%$ sand; and S6 - $100 \%$ BSB. The development of cabbage seedlings was evaluated at 30 days after sowing, with data being submitted to variance analysis followed by Duncan's test to identify significant treatment effects at the $5 \%$ probability level. We accordingly found that the use of an alternative substrate, formulated based on babassu stem biomass, had beneficial effects with respect to promoting cabbage seedling growth. On the basis of the findings of this study, we recommend the use of a substrate comprising $60 \%$ babassu stem biomass and $40 \%$ sand for the vigorous growth of ' 60 days' cabbage seedlings.

Keywords: Attalea speciosa Mart.; Brassica oleracea; growth; quality; vegetable.

Abbreviations: BSB_biomass of the stems of babassu; S_substrate; DAS_days after sowing; LN_number of leaves; HP_height of the plant; SD_ stem diameter; RL_ root length; RV_ volume of roots; MFPA_ fresh mass of aerial parts; MFR_fresh root mass; MDPA_ dry mass of aerial parts; MDR_ root dry mass; $\mathrm{MDT}_{-}$total dry mass; DQI_ Dickson quality index.

\section{Introduction}

Cabbage (Brassica oleracea) is the economically most important vegetable in the Brassicaceae family, which is widely consumed in human diets and associated with an excellent nutritional value. In Brazil, it is the fifth most widely produced vegetable and one of the most popular and accessible foods, with high socioeconomic importance to rural producers and Brazilian consumers. When wellmanaged, plants of the '60 days' cabbage cultivar are vigorous and produce medium-sized round heads ranging in weight from 2 to $2.5 \mathrm{~kg}$ per unit, with green foliage and a growth cycle of 90 to 100 days (Perin et al., 2015).

From the perspective of current-day vegetable production, the raising of seedlings constitutes one of the most important stages of the cultivation system, which is necessary to enhance competitiveness and economic profitability. The increasing demand for higher food production and the need to provide nutrients for plants drive the development of research in the agricultural sector, particularly with respect to seedling production and protected cultivation (Lopes et al., 2017).

The substrate used for seedling production should promote efficient germination and seedling emergence, in addition to providing adequate nutrients and oxygen supply. In order to achieve these goals, the substrate must accordingly have good physical, chemical, biological, and sanitary characteristics (Medeiros et al., 2014). Among the various substrate options available in Brazil, there are regional alternatives, one of which is a substrate derived from babassu stem biomass.

The decaying trunks of babassu palm (Attalea speciosa Mart.), which originates from the North and Northeast regions of Brazil, are widely available in the soils of woods, and these are collected by smallholders for use as substrates for seedling production (Oliveira et al., 2018). Recent studies have shown satisfactory results when using babassu stem biomass in production of the seedlings of melon plant (Cucumis melo L.) (Cordeiro et al., 2018), pomegranate tree 'Wonderful' (Punica granatum L.) (Oliveira Neto et al., 2018), 
and great bougainvillea (Bougainvillea spectabilis Willd.) (Cruz et al., 2018).

Given the potential utility of using babassu stem biomass, the provision of technical information relating to the use of substrates based on this natural resource can promote greater sustainability in the production of vigorous vegetable seedlings. In this study, we accordingly sought to evaluate seedling growth of the ' 60 days' cabbage cultivar in substrates based on babassu stem biomass.

\section{Results and Discussion}

On the basis of variance analysis, we were able to verify that there were significant effects $(p<0.01)$ regarding the use of babassu stem biomass on virtually all analyzed variables, with the one exception being shoot dry mass.

We found that seedlings raised in a substrate comprising $60 \% \mathrm{BSB}+40 \%$ sand produced the highest mean number of leaves (4.03 leaves) (Table 1). Given that Filgueira (2013) suggests that cabbage seedlings should be transplanted at approximately the 4-leaf stage, this value indicates that seedlings grown on the $60 \%$ BSB $+40 \%$ sand formulation would be available for transplantation at an earlier date than those grown on other formulations. We speculate that the observed differences in leaf number are attributable to differing levels of nutrients contained in the different substrates, particularly nitrogen, which has a pronounced effect on plant growth (Table 3). This assumption is consistent with the findings of Moreira et al. (2011), who observed that the number of cabbage leaves increases linearly with an increase in nitrogen dosage. However, for seedlings grown on substrates with babassu stem biomass proportions of $80 \%$ and $100 \%$, there was a slight decrease in the number of leaves, possibly due to higher substrate porosity, which may have caused higher leaching of some nutrients during irrigation (Tables 1 and 4).

Consistently, we observed that the maximum value for plant height $(3.84 \mathrm{~cm})$ was also obtained for seedlings raised in the $60 \%$ BSB $+40 \%$ sand substrate. Costa et al. (2014), who used a range of substrates for the production of cabbage seedlings, obtained a significant growth of $8.27 \mathrm{~cm}$ in plant height and concluded that the substrate provided favorable physical, chemical, and biological conditions for shoot development. However, similar to leaf number, we observed decreases in the height of seedlings rose in substrates with babassu stem biomass proportions of $80 \%$ and $100 \%$, which we again suspect could be related to higher substrate porosity that may have been more conducive to nutrient leaching (Table 4).

Stem diameter appeared to be less dependent on the proportions of babassu stem biomass, with better yields obtained for seedlings grown on $100 \%$ sand, $20 \%$ BSB $+80 \%$ sand, and $60 \%$ BSB $+40 \%$ sand substrates (Table 1 ). These results are similar to those obtained for leaf number and plant height and corroborate the findings of Albano et al. (2017), who observed a relationship between an increase in stem diameter and plant height. According to these authors, an increase in height facilitates a greater accumulation of photoassimilates that culminate in enhanced vertical yield (height) and horizontalization (diameter) of seedlings, and we speculate that these growth responses could be attributable to the levels of potassium (Table 3 ) contained in the substrate.

According to Valeri and Corradine (2005), potassium, when available in adequate quantities, promotes thickening of seedling stems during the production phase. An increase in stem diameter in turn improves the performance of plants in terms of vigor, robustness, and heightened resistance to lodging and pest infestation (Cruz et al., 2013). In this regard, it is important to highlight that although there were similar results among the different substrates used, the $60 \%$ $\mathrm{BSB}+40 \%$ sand substrate would still be considered superior, on account of the higher values obtained for other important variables of seedling growth.

The $60 \%$ BSB $+40 \%$ sand substrate was also found to promote the highest growth in root length, with a mean value of $11.04 \mathrm{~cm}$ being recorded (Table 1). In this regard, Santos et al. (2005) examined the utility of Plantmax, Bioterra, and filter cake as substrates in the production of cabbage seedlings, and accordingly found that seedlings raised on filter cake as substrate, with a mean root length of $6.37 \mathrm{~cm}$, outperformed those grown on the other two substrates. Lima et al. (2006) observed that the use of plant materials of small particle size in substrate composition is conducive to the rapid release of nutrients during seedling production, thereby contributing to an improvement in substrate aeration, which is one of the most important factors associated with the promotion of root growth. Similar to the aforementioned variables, we detected a reduction in the root length of seedling grown on substrates with BSB proportions of $80 \%$ and $100 \%$, which again could be ascribed to the leaching of water and nutrients, and is conceivably related to interference in root cell division that consequently retarded root development.

With respect to root volume, the best results were obtained using substrates S1, S2, and S4, with comparatively lower volumes being detected in those seedlings grown on substrates S5 and S6 (Table 1). Previously Röder et al. (2015) examined the effects on cabbage seedlings of increasing doses of biofertilizer obtained from sugarcane molasses fermented by the bacterium Corynebacterium glutamicum (AG30), which contained $30 \%$ L-glutamic acid and $6 \%$ organic carbon, and observed that seedling root volume showed a linear increase, as a function of increasing AG30 concentration. The positive response of root volume related to the use of BSB in the $60 \% \mathrm{BSB}+40 \%$ sand substrate can probably be attributed to the physical and chemical properties of the material, mainly associated with porosity and density (Table 4) that contribute to aeration and retention of water, up to a certain proportion in the formulation. These properties would be assumed to favor more efficient root exploration, and, thus, more satisfactory development.

Seedlings raised in the $60 \%$ BSB $+40 \%$ sand substrate also showed the highest fresh mass of aerial parts, with a mean value of $0.14 \mathrm{~g}$. Previously, Ensinas et al. (2011), who evaluated the effects of using commercial substrate and different proportions of humus on seedling development of the brassica crop arugula, observed an increase in MFPA $(4.73 \mathrm{~g})$ only when using the commercial substrate. We suspect that an increase in the MFPA of cabbage seedlings in response to cultivation in BSB-containing substrate can probably be ascribed to the influence of the physical and chemical properties of stem biomass with regards to water retention and nutrient availability, which contribute to better seedling growth.

The yield of root fresh mass obtained was also highest $(0.20$ g) for seedlings grown on the $60 \%$ BSB $+40 \%$ sand substrate (Table 2). Santana et al. (2011) evaluated the development of cabbage seedlings in substrates composed of sisal residue 
Table 1. The significance of effects on the variables leaf number (LN), plant height (HP), stem diameter (SD), root length (RL), and root volume (RV) of cabbage seedlings as a function an increasing proportions of babassu stem biomass (BSB) in substrates

\begin{tabular}{|c|c|c|c|c|c|}
\hline Substrates & LN & $\begin{array}{c}\mathrm{HP} \\
---\mathrm{cm}---\end{array}$ & $\begin{array}{l}\text { SD } \\
---m m---\end{array}$ & $\begin{array}{l}\mathrm{RL} \\
---\mathrm{cm}---\end{array}$ & $\begin{array}{l}\mathrm{RV} \\
---\mathrm{cm}^{3}---\end{array}$ \\
\hline S1 & $3.04 c$ & $2.76 \mathrm{~b}$ & $0.92 \mathrm{a}$ & $8.38 a b$ & $0.30 \mathrm{a}$ \\
\hline S2 & $3.36 \mathrm{bc}$ & $2.80 \mathrm{~b}$ & $0.98 \mathrm{a}$ & $8.41 \mathrm{~b}$ & $0.30 \mathrm{a}$ \\
\hline S3 & 3.26 bc & $2.80 \mathrm{~b}$ & $0.83 a b$ & $9.19 a b$ & $0.25 a b$ \\
\hline S4 & $4.03 \mathrm{a}$ & $3.84 \mathrm{a}$ & $0.89 a$ & $11.04 \mathrm{a}$ & $0.30 \mathrm{a}$ \\
\hline S5 & $3.53 \mathrm{abc}$ & $2.97 \mathrm{~b}$ & $0.82 a b$ & $8.31 \mathrm{~b}$ & $0.14 \mathrm{~b}$ \\
\hline S6 & $3.75 \mathrm{ab}$ & $2.72 \mathrm{~b}$ & $0.56 \mathrm{ab}$ & $7.04 \mathrm{~b}$ & $0.13 \mathrm{~b}$ \\
\hline $\mathrm{CV}(\%)$ & 11.22 & 8.75 & 21.92 & 18.19 & 30.47 \\
\hline
\end{tabular}

probability, as determined using the $\mathrm{F}$ test; $n \mathrm{~ns}$ not significant.

Table 2. The significance to the variables shoot fresh weight (MFPA), root fresh mass (MFR), dry mass of aerial parts (MDPA), root dry mass (MDR), and Dickson quality index (DQI) of cabbage seedlings as a function of an increasing proportion of babassu stem biomass (BSB) in substrates

\begin{tabular}{llllll}
\hline Substrates & MFPA & MFR & MDPA & MDR & DQI \\
\hline S1 & $--.07 \mathrm{c}$ & $0.14 \mathrm{~b}$ & $0.01 \mathrm{a}$ & $0.01 \mathrm{a}$ & $3.50 \mathrm{~b}$ \\
S2 & $0.07 \mathrm{c}$ & $0.10 \mathrm{bc}$ & $0.01 \mathrm{a}$ & $0.0032 \mathrm{ab}$ & $4.04 \mathrm{ab}$ \\
S3 & $0.07 \mathrm{c}$ & $0.10 \mathrm{bc}$ & $0.01 \mathrm{a}$ & $0.0038 \mathrm{ab}$ & $6.12 \mathrm{ab}$ \\
S4 & $0.14 \mathrm{a}$ & $0.20 \mathrm{a}$ & $0.01 \mathrm{a}$ & $0.01 \mathrm{a}$ & $7.17 \mathrm{a}$ \\
S5 & $0.10 \mathrm{bc}$ & $0.07 \mathrm{~cd}$ & $0.01 \mathrm{a}$ & $0.0017 \mathrm{~b}$ & $2.95 \mathrm{~b}$ \\
S6 & $0.12 \mathrm{ab}$ & $0.06 \mathrm{~d}$ & $0.01 \mathrm{a}$ & $0.0020 \mathrm{~b}$ & $2.75 \mathrm{~b}$ \\
\hline CV (\%) & 23.23 & 24.48 & 14.87 & 19.88 & 50.69 \\
\hline
\end{tabular}

S1 - 100\% sand; $52-20 \% \mathrm{BSB}+80 \%$ sand; $53-40 \% \mathrm{BSB}+60 \%$ sand; $54-60 \% \mathrm{BSB}+40 \%$ sand; $55-80 \% \mathrm{BSB}+20 \%$ sand; $56-100 \% \mathrm{BBB}$; CV: coefficient of de variation; *: Significant at the $5 \%$ level of probability, as determined using the $\mathrm{F}$ test; $\mathrm{ns}$ : not significant.

Table 3. $\mathrm{pH}$ values, electrical conductivity (EC), and total nitrogen $(\mathrm{N})$, phosphorus (P), potassium (K), calcium (Ca), magnesium $(\mathrm{Mg})$, and sulfur (S) content of sand and babassu stem biomass (BSB) substrates

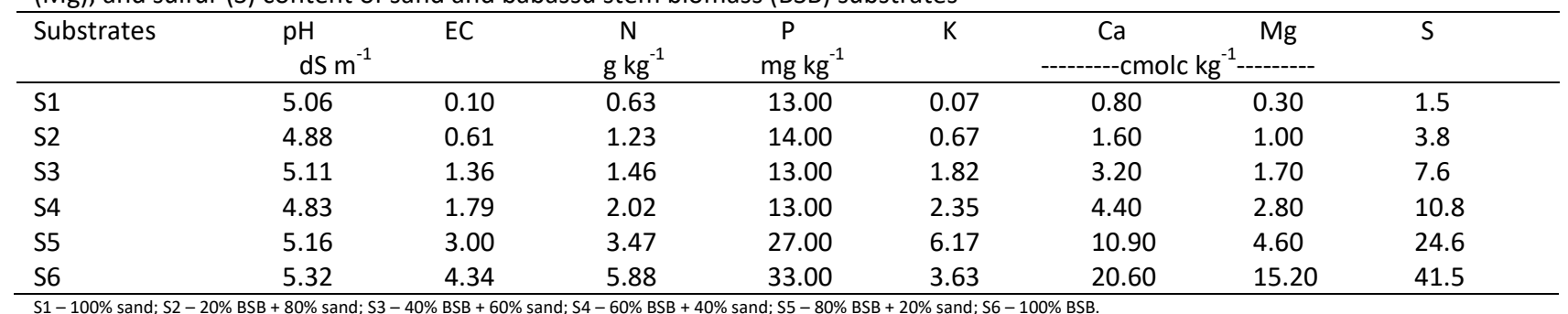

Table 4. Global density (GD), particle density (PD), and porosity (P) of the sand and babassu stem biomass (BSB) substrates

\begin{tabular}{llll}
\hline \multicolumn{2}{c}{$\begin{array}{c}\text { Substrate } \\
\text { GD }\end{array}$} & Density $\left(\mathrm{g} / \mathrm{cm}^{3}\right)$ & Porosity (\%) \\
\hline S1 & 1.44 & 2.67 & 45.99 \\
S2 & 1.28 & 2.64 & 51.53 \\
S3 & 1.18 & 2.57 & 54.01 \\
S4 & 0.98 & 2.24 & 56.22 \\
S5 & 0.73 & 1.88 & 60.91 \\
S6 & 0.33 & 0.97 & 65.95 \\
\hline S1-100\% sand; S2-20\% BSB + 80\% sand; S3-40\% BSB + 60\% sand; S4-60\% BSB + 40\% sand; S5-80\% BSB + 20\% sand; S6- 100\% BSB.
\end{tabular}


plus commercial substrate, and accordingly found that a substrate comprising $40 \%$ tropstrate $+60 \%$ sisal bagasse promoted development of the highest average of the fresh mass of the root system $(0.19 \mathrm{~g})$. According to these authors, this effect is probably due to the availability of water and nutrients in the substrate, as well as the porosity, which may have generated a favorable environment for the roots to explore the substrate and consequently develop further. In the present study, we therefore consider it probable that at proportions of babassu stem biomass in the substrate greater than $60 \%$, there was less water retention and availability, with consequent negative effects on growth. Unlike the aforementioned plant variables, the shoot dry mass of cabbage seedlings did not appear to be influenced by the substrates we assessed, which tends to contrast with the findings of Crippa and Ferreira (2015), who observed a significant difference in the development of cabbage seedlings when using different substrates in trays of differing size. We suspect that this disparity in observations could be attributable to the short evaluation time of the present study (30 days). Although there was an increase in fresh mass through better water retention in the substrate, this accumulation did not result in a gain in dry material. Had we examined growth over an extended period of development, it is plausible that we would have detected significant differences in dry mass, particularly when using 60\% BSB + $40 \%$ sand. Consistent with this assumption, Magro et al. (2011), who evaluated cabbage seedlings at 37, 41, 45, 49, and 53 days after sowing, found that 37 -day-old seedlings had a weight gain of $1.4 \mathrm{~g}$ in shoot dry mass, whereas 53day-old seedlings yielded a weight of $9.9 \mathrm{~g}$.

In contrast to shoot dry mass, which showed no significant increase, we found that the root dry mass of cabbage seedlings was promoted when using the $60 \%$ BSB $+40 \%$ sand substrate (Table 2). Cimó et al. (2017), who evaluated the influence of phosphorus dosage during the fertirrigation of cabbage seedlings grown in coconut fiber substrate, observed a linear increase in seedling root dry mass with an increase in the amount of applied phosphorus.

We speculate that the increase in the root dry mass of cabbage seedlings raised in the $60 \%$ BSB $+40 \%$ sand substrate can be attributed to the favorable proportions of this substrate that provide the optimal chemical and physical conditions for seedling growth, particularly with respect to phosphorus. At babassu stem biomass proportions higher than $60 \%$, we noted a decrease in MDR, possibly due to a more rapid leaching of nutrients and water.

With respect to the Dickson quality index (DQI), we observed an increase in index values for ' 60 days' cabbage seedlings concomitant with an increasing proportion of babassu stem biomass in substrates up to $60 \%$, with a mean value of 7.17 observed for seedlings grown on the $60 \%$ BSB $+40 \%$ sand substrate. In this regard, Ferreira et al. (2017), who evaluated the effect of commercial substrate and conditioners on the quality of arugula seedlings, found that the best substrates in terms of DQI were those containing conditioners (charcoal rice husk, dry coconut husk, kapok branch, and straw strain).

It is important to highlight the marked decreases in the DQI value of seedling grown on substrates S5 and S6 when compared with $\mathrm{S} 4$ in the present study, which we assume is associated with the corresponding decreases in MDT, HP, $\mathrm{SD}, \mathrm{MDPA}$, and MDR, the main parameters contributing to the DQI, when using substrates S5 and S6.
Sousa et al. (2015) suggest that DQI is indicative of the quality of seedling, and consistently Bernardinho et al. (2005) noted that a higher DQI is associated better seedling quality. In this context, we believe that the use of a $60 \%$ BSB $+40 \%$ sand substrate is beneficial to the growth of cabbage seedlings, in terms of both rooting and shooting characteristics.

Accordingly, this substrate can be recommended as an effective alternative for the cultivation of cabbage seedlings in the state of Maranhão, Brazil, where the raw material for its formulation is particularly abundant and has been little exploited from an economic perspective. We thus believe that the use of this substrate will have positive implications for sustainable development and contribute to increases in the incomes of small producers.

\section{Materials and Methods}

\section{Location and experimental design}

The experiment was conducted during the period from September to October 2018 at the Agricultural and Environmental Sciences Centre (CAAC) of the Federal University of Maranhão (UFMA) (south latitude: $03^{\circ} 44^{\prime} 17^{\prime \prime}$,

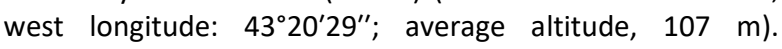
According to the Köppen classification, the climate of the region is characterized as Tropical Humid. The region has an annual average rainfall of $1613.2 \mathrm{~mm}$ and an average annual temperature of $27.9^{\circ} \mathrm{C}$ (Passos et al., 2016).

Plants were grown on a greenhouse covered by a shade screen providing $50 \%$ light interception. The experimental design was one of randomized blocks with six treatments, four replications, and eight plants per replicate. The treatments consisted in different substrate $(S)$ formulations based on a mixture of biomass derived from the stems of babassu (BSB) and sand: S1 - 100\% sand; S2 - 20\% BSB + 80\% sand; S3 - $40 \%$ BSB $+60 \%$ sand; S4 - $60 \%$ BSB $+40 \%$ sand; S5 $80 \%$ BSB $+20 \%$ sand; S6 - 100\% BSB. The babassu stems were collected in a forest where babassu palm trees had fallen and were decaying. The collected material was subsequently screened through a $8-\mathrm{mm}$ mesh to obtain a babassu stem biomass that could be readily homogenized during substrate formulation. The biomass substrate thus obtained was then mixed with sand in 1-L containers in the aforementioned proportions.

Two seeds of the ' 60 days' cabbage cultivar were sown in each cell of 128-cell polyethylene trays at a depth of $1 \mathrm{~cm}$, and at 15 days after sowing (DAS), thinning was performed, such that only the most vigorous seedling was left to grow in each cell. During the experiment, two irrigations were performed daily via a 2-L manual irrigator.

\section{Chemical and physical analyses}

Prior to setting up of the experiment, we conducted chemical and physical analyses of the substrates (Tables 3 and 4), as well as particle size analysis of the sand samples used in the substrates. The soil from which the sand samples were collected, which according to Santos et al. (2013) is classified as a Yellow Dystrophic Latosoil with a sandy texture, had the following composition: $780 \mathrm{~g} / \mathrm{kg}$ of sand, 90 $\mathrm{g} / \mathrm{kg}$ of silt, and $130 \mathrm{~g} / \mathrm{kg}$ of total clay. 


\section{Measured characters}

At 30 DAS, we evaluated the following variables: number of leaves (LN) - determined by manual counting of the total number of completely expanded leaves on each plant; plant height (HP: $\mathrm{cm}$ ) - obtained by measuring from ground level to the apex of the plant with the aid of a ruler; stem diameter (SD: $\mathrm{mm}$ ) - measured by positioning a digital caliper at the medial portion of the stem; root length (RL: $\mathrm{cm})$ - measured from the cervix to the apex of the largest root with the aid of a ruler; root volume (RV: $\mathrm{cm}^{3}$ ) - obtained by measuring the displacement of a water column into a test tube (Basso, 1999); shoot fresh weight (MFPA: g) and fresh root mass (MFR: g) - defined by weighing the shoot material and root system, respectively, on a semi-analytical balance; shoot dry mass (MDPA: g) and root dry mass (MDR: g) obtained by drying the material in a forced air circulation oven at a temperature of $65^{\circ} \mathrm{C}$ for $72 \mathrm{~h}$, and then weighing on a semi-analytical balance; and the Dickson quality index (DQI) - estimated using the following formula described by Dickson et al. (1960):

$D Q I=\frac{M D T(g)}{H P(c m) / S D(m m)+\operatorname{MDPA}(g) / M S R(g)}$

where MDT is total dry mass, HP is plant height, SD is stem diameter, MDPA is shoot dry mass; and MDR is root dry mass.

\section{Statistical analysis}

In order to determine significant effects, the data were submitted to analysis of variance, and the treatments were compared using Duncan's test at the $5 \%$ of probability level using Infostat version 20151 software (Di Rienzo et al., 2011).

\section{Conclusion}

In this study, we found that the use of an alternative growth substrate, formulated with a base of babassu stem biomass, is beneficial to the growth of cabbage seedlings. When mixed in appropriate proportions with sand, babassu stem biomass can enhance the physical and chemical properties of the substrate, thereby favoring the production of cabbage seedlings and promoting more vigorous growth. On the basis of our findings, we recommend the use of a substrate with a $60 \%$ babassu stem biomass plus $40 \%$ sand formulation for promoting the vigorous development of ' 60 days' cabbage.

\section{Acknowledgments}

We would like to thank Editage (www.editage.com) for English language editing. We gratefully acknowledge the Federal University of Maranhão (UFMA), the National Council for Scientific and Technological Development (CNPq), and Coordination for the Improvement of Higher Level Personnel (CAPES).

\section{References}

Albano FF (2017) New substrate containing agroindustrial carnaúba residue for production of papaya under foliar fertilization. Rev Bra de Eng Agríc e Ambient. 21(2):128133.
Andrade HAF, Costa NA, Cordeiro KV, Oliveira-Neto ED, Albano FG, Silva-Matos RRS (2017) Caule decomposto de babaçu (Attlea speciosa Mart.) como substrato para produção de mudas de melancieira. Cul Agron. 26(3):406416.

Basso SMS (1999) Caracterização morfológica e fixação biológica de nitrogênio de espécies de Adesmia DC e Lotus L. $268 \mathrm{f}$. Tese (Doutorado em Zootecnia) -Universidade Federal do Rio Grande do Sul, Porto Alegre.

Bernardinho DCS, Paiva HN, Neves JCL, Gomes JM, Marques VB (2005) Crescimento e qualidade de mudas de Anadenanthera macrocarpa (Benth) Brenan em respostas à saturação por bases do substrato. Rev Árvore. 29(6):863-870.

Cimó L, Candian JS, Colombari LF, Redigolo MVN, Cardoso All (2017) Doses de fósforo na fertirrigação de mudas em substrato a base de fibra de coco e influência na produção do repolho. Irriga. 22(1):34-43.

Cordeiro KV, Andrade HAF, Oliveira-Neto ED, Costa NAC, Rocha BR, Pontes SF, Marzullo YOT, Pinto FEN, Machado NAF, Silva-Matos RRS (2018) New substrates based on decomposed babassu (Attalea speciosa Mart.) stem in the production of melon seedlings. J Exp Agric Int. 26(1):1-7.

Costa LAM, Pereira DC, Costa MSSM (2014) Substratos alternativos para produção de repolho e beterraba em consórcio e monocultivo. Rev Bra Eng Agríc Ambient. 18 (2):150-156.

Crippa JPB, Ferreira LG (2015) Desenvolvimento de mudas de repolho em diferentes tipos de bandeja e substrato. Rev Conn Line. 1(12):6--10.

Cruz AC, Lima JS, Andrade HAF, Oliveira ARF, Leite MRL, Silva LR, Silva TF, Gondim MMS, Machado NAF, Silva-Matos RRS (2018) Stalk decomposed babassu for production of seedlings of Bougainvillea spectabilis Willd, in different levels of indole butyric acid. Asian Acad Res J Multidis. 5(1):98-107.

Cruz RN, Azevedo CAV, Fernandes JD, Monteiro Filho AF, Wanderley JAC (2013) Adubação orgânica residual no crescimento e produção do gergelim irrigado com água residuária. Rev Verde Agroecologia Desenvolv Sustent. 8(1):257-263.

Di Rienzo JA, Casanoves F, Balzarini MG, Gonzales L, Tablada M, Robledo CW (2011) Infostat version 2011. Grupo InFostat, Faculdade de Ciências Agropecuárias, Universidad Nacional de Córdoba, Argentina. 8(1):195199.

Dickson A, Leaf AL, Hosner J F (1960) Quality appraisal of white spruce and white pine seedling stock in nurseries. Forest Chron. 36 (1):10-13.

Ensinas SC, Junior MTM, Ensinas BC (2011) Desenvolvimento de mudas de rúcula em diferentes combinações de substrato. Rev Cient Eletrôn Agron. 18 (1):1-7.

Ferreira RLF, Araújo Neto SE, Alves GKEB, Simões AC, Boldt RH (2017) Qualidade de mudas e produtividade de rúcula em função de condicionadores de substratos. Agropec Cient Semiár. 13 (3):179-186.

Filgueira FAR (2013) Novo manual de olericultura: agrotecnologia moderna na produção e comercialização de hortaliças. 3. ed. rev. e ampl. Viçosa, MG: UFV. 421 p.

Lima RLS, Severino LS, Silva MIL, Jerônimo JF, Vale LS, Beltrão NEM (2006) Substratos para produção de mudas de mamoneira compostos por misturas de 342 cinco fontes de matéria orgânica. Ciênc Agrotec. 30 (3):474-479. 
Lopes MC, Cardoso SS, LUCAS FT, Melo VA (2017) Efeito da aplicação foliar de biofertilizante na produção de mudasde rúcula sob diferentes substratos. Nucleus. 14 (1):177-188.

Magro FO, Salata AC, Cardoso All (2011) Produção de repolho em função da idade das mudas. AgroAmbiente. 5(2):119-123.

Medeiros AS, Silva EG, Luison EA, Andreani Júnior R, Andreani D I K (2010) Utilização de compostos orgânicos para uso como substratos na produção de mudas de alface. Agrarian. 18(3):261-266.

Moreira MA,Vidigal SM, Sediyama MAN, Santos MR (2011) Crescimento e produção de repolho em função de doses de nitrogênio. Hort Bras. 29(1):117-121.

Oliveira Neto ED, Andrade HAF, Oliveira ARF, Moraes LF, Santos LR, Pontes SF, Costa NA, Lopes PRC, Oliveira IVM, Silva-Matos RRS (2018) Vegetative propagation of pomegranate 'Wonderful' in substrates of decomposed babassu stem. Asian Acad Res J Multidis. 5(1):167-179.

Passos MLV, Zambrzycki GC, Pereira RS (2016) Balanço hídrico e classificação climática para uma determinada região de Chapadinha-MA. Rev Bras Agric Irrig. 10(4):758766.
Perin A, Cruvinel DA, Ferreira HS, Melo GB, Lima LE, Andrade JWS (2015) Decomposição da palhada e produção de repolho em sistema plantio direto. Global Sci Technol. 8(2):153-159

Röder C (2015) Uso de biofertilizante na produção de mudas de repolho. Rev Ceres. 62(5):502-505.

Santana AGS, Rios ES, Santos NT, Souza DA, Oliveira AC, Silva MJR, Aragão CA (2011) Efeitos da utilização de diferentes substratos para obtenção de mudas de Repolho. Hort Bras. 29(2):1-5.

Santos ACP (2005) Utilização de torta de filtro como substrato para a produção de mudas de hortaliças. Coll Agr. 1(2):1-5.

Santos HG (2013) Sistema brasileiro de classificação de solos. 3a ed. Rio de Janeiro, Embrapa, p. 353.

Sousa LB, Nóbrega RSA, Lustosa Filho JF, Nascimento Amorim SPN, Ferreira LVM, Nóbrega JCA (2015) Cultivo de Sesbania virgate (Cav Pers) em diferentes substratos. Rev Cienc Agrar. 58(3):240-247.

Valeri SV, Corradini L (2005) Fertilização em viveiros para a produção de mudas de Eucalyptus e Pinus. In: Gonçalves JLM, Benedetti $\vee(E d$.$) Nutrição e fertilização florestal.$ Piracicaba: Instituto de Pesquisas e Estudos Florestais. p. 167-190. 